\title{
IIIISGUC.ORG
}

"iș, GÜC̣" ENDÜSTRi iLișKiLERi VE INSAN KAYNAKLARI DERGISi

"IS, GUC" INDUSTRIAL RELATIONS AND HUMAN RESOURCES JOURNAL

\section{İşsizlikle Mücadelede İş Danışmanlık Hizmetleri ve Yalova Örneği}

\author{
Job Counseling Services in The Fight Against \\ Unemployment: The Survey Of Yalova
}

\author{
Orhan KOÇAK \\ Yrd.Doç.Dr., Yalova Üniversitesi, İ̈BF \\ Ahmet Cahit AKMAN \\ İş Danışmanı, Yalova İşKUR İl Müdürlüğü
}

Nisan/April 2011, Cilt/Vol: 13, Sayı/Num: 2, Page: 133-154

ISSN: 1303-2860, DOI: 10.4026/1303-2860.2010.0177.x

\footnotetext{
Makalenin on-line kopyasına erişmek için:

http://www.isguc.org/?p=article\&id=460\&vol=13\&num=2\&year=2011

To reach the on-line copy of article:

http://www.isguc.org/?p=article\&id=460\&vol=13\&num=2\&year=2011

Makale İçin İletişim/Correspondence to:

Orhan KOÇAK: okocak@yalova.edu.tr
} 
(C) 2000- 2011

"İşGüç" Endüstri İlişkileri ve İnsan Kaynakları Dergisi

"İşGüç" Industrial Relations and Human Resources Journal

Nisan/April 2011, Cilt/Vol: 13, Say1/Num: 2

ISSN: 1303-2860, DOI: 10.4026/1303-2860.2010.177.x

Editör/Editor-in-Chief

Aşkın Keser (Kocaeli University)

Editör Yardımcıları/Co-Editors

K.Ahmet Sevimli (Uludağ University)

Gözde Yılmaz (Kocaeli University)

Uygulama/Design

Yusuf Budak (Kocaeli Universtiy)

\author{
Yayin Kurulu / Publishing Committee \\ Dr.Zerrin Firat (Uludă̆ University) \\ Doç.Dr.Așkm Keser (Kocaeli University) \\ Prof.Dr.Ahmet Selamoğlu (Kocaeli University) \\ Yrd.Doç.Dr.Ahmet Sevimli (Uludağ University) \\ Yrd.Doç.Dr.Abdulkadir Şenkal (Kocaeli University) \\ Yrd.Doç.Dr.Gözde Yilmaz (Kocaeli University) \\ Dr.Memet Zencirkıran (Uludă̆ University)
}

Uluslararası Danışma Kurulu / International Advisory Board

Prof.Dr.Ronald Burke (York University-Kanada)

Assoc.Prof.Dr.Glenn Dawes (James Cook University-Avustralya)

Prof.Dr.Jan Dul (Erasmus University-Hollanda)

Prof.Dr.Alev Efendioğlu (University of San Francisco-ABD)

Prof.Dr.Adrian Furnham (University College London-İngiltere)

Prof.Dr.Alan Geare (University of Otago- Yeni Zellanda)

Prof.Dr. Ricky Griffin (TAMU-Texas AEM University-ABD)

Assoc. Prof. Dr. Diana Lipinskiene (Kaunos University-Litvanya)

Prof.Dr.George Manning (Northern Kentucky University-ABD)

Prof. Dr. William (L.) Murray (University of San Francisco-ABD)

Prof.Dr.Mustafa Özbilgin (University of East Anglia-UK)

Assoc. Prof. Owen Stanley (James Cook University-Avustralya)

Prof.Dr.Işık Urla Zeytinoğlu (McMaster University-Kanada)

Danışma Kurulu / National Advisory Board

Prof.Dr.Yusuf Alper (Uludağ University)

Prof.Dr.Veysel Bozkurt (Uludağ University)

Prof.Dr.Toker Dereli (Işık University)

Prof.Dr.Nihat Erdoğmuş (Kocaeli University)

Prof.Dr.Ahmet Makal (Ankara University)

Prof.Dr.Ahmet Selamoğlu (Kocaeli University)

Prof.Dr.Nadir Suğur (Anadolu University)

Prof.Dr.Nursel Telman (Maltepe University)

Prof.Dr.Cavide Uyargil (İstanbul University)

Prof.Dr.Engin Yildirum (Sakarya University)

Doç.Dr.Arzu Wasti (Sabancı University)

Dergide yayınlanan yazılardaki görüşler ve bu konudaki sorumluluk yazarlarına aittir.

Yayınlanan eserlerde yer alan tüm içerik kaynak gösterilmeden kullanılamaz.

All the opinions written in articles are under responsibilities of the outhors.

None of the contents published can't be used without being cited. 


\title{
İşsizlikle Mücadelede İş Danışmanlık Hizmetleri ve Yalova Örneği
}

\author{
Job Counseling Services in The FightAgainst Unemployment: \\ The Survey Of Yalova
}

\author{
Orhan KOÇAK \\ Yalova Üniversitesi
}

\author{
Ahmet Cahit AKMAN \\ Yalova İŞKUR İl Müdürlüğü
}

\begin{abstract}
Özet:
İșsiz olanlarm, işsizliğin yoğun olduğu dönemlerde iș arama sürelerinin uzun olması ve bu uzun süre içerisinde iş bulamamaları, olumsuz etkilenmelerini sağlamaktadır. Böyle bir süreç, hem işsizliği artırmakta hem de bireysel ve toplumsal sorunların artışını beraberinde getirmektedir. İşarayanlar bu süreç içerisinde desteksiz kalarak işsiz sayısını artırmakta ve bir danışmanla görüşmeden girilen işyerlerinde mutlu olamamaktadırlar.

İşsizlerin iş arama sürecinde, iş arama yöntemleri konusunda bilgi sahibi olmaları ve durumlarna en uygun işi seçebilmelerinin sağlanması ile ülkenin sahip olduğu insan kaynağı daha etkin ve verimli kullanılabilecektir. Bu hedeflere ulaşılmasına yardımcı olan iş danışmanlığı hizmetleri, finansal kriz sonrasında önem kazanmaktadır.

Bu çalışmada işsizlik sorununun çözümünde iş danışmanlığı hizmetlerinin önemi ve iş arayanların bu hizmetlere olan yaklaşımları ve farkındalık düzeyi değerlendirilecektir. Yalova ilinde bu hizmetin hangi düzeyde olduğu yapılan anketin değerlendirilmesi ile anlaşılmaya çalışılacaktır.
\end{abstract}

Anahtar kelimeler: İŞKUR, İş Danışmanlı̆̆ı, İssizlik

\begin{abstract}
:
Jobless people are negatively affected in the period, when unemployment rate is very high, if the job searching process is very long and they can't find a job in the long process. This process both increases the rate of unemployment and the problems of society. In this period, if the unemployed find a job, without the guidance of a job counselor, they may be unsatisfied with the job they find.

Human resources in a country, is going to be more effective and productive provided that they get proper information about job searching and its methods. If so, they will be able to choose the best one during the process of job searching. Job counseling services that help in reaching these aims are becoming more important after the financial crises.

The level of awareness and the approach of jobless people to the value of job counseling services and their importance in the fight against unemployment is evaluated in this paper. The survey that was conducted in Yalova, is going to be investigated to understand the level of the services.
\end{abstract}

Keywords: İŞKUR, Job Counseling, Unemployment 


\section{Giriş}

İşsizlik sorunu ülkemiz ve birçok dünya ülkesi açısından çözüm bekleyen sorunların başında gelmektedir. Aynı zamanda işsizlik birçok sorunun da kaynağı olarak gösterilmektedir. Günümüz işgücü piyasası çok hızlı değişmekte ve iş piyasasının ihtiyaç duyduğu gereksinmeler de bu hızlı değişimden etkilenmektedir. Her birey iș aramaya bașlarken bu değişim sürecini iyi algılayabilmeli ve değişimin gerisinde kalmamalıdır.

Ülkemizde işsizliğge neden olan birçok faktör bulunmakta ve işsizlik yoğun bir şekilde hissedilmektedir. İsssizliğin yoğun olarak hissedildiği bir ülkede işsiz durumda olan bireylere yönelik sunulan iş danışmanlığı hizmetinin etkinleştirilmesi, işsizliğin azaltılmasında son derece önemlidir. $\mathrm{Bu}$ nedenle iș danışmanlığ 1 konusu, hem önemi hem de gündemde olması nedeniyle teorik ve uygulama yönü ile çalışılmaya gerek görülmüştür.

Çalışmanın kavramsal çerçeve kısmında işsizlik, iş danışmanlığ 1 , işgücü piyasası ve ülkemizdeki işsizlik oranlarından bahsedilmiş, ikinci kısımda bazı ülkeler ve Türkiye İş Kurumundaki iş danışmanlığı uygulamalarına değinilmiştir. Son bölümde ise iş danışmanlığ1 konusunda iş arayanların farkındalık düzeyi ve hizmetin muhtemel faydalarınin belirlenmesi konusunda toplam 112 iş arayana uygulanan anket sonuçları SPSS 17 programinda değerlendirilerek, yorumları İş danışmanlığı hizmeti üzerine bir alan araştırması başlığı altında incelenmiştir.

\section{KAVRAMSAL ÇERÇEVE}

\section{1. İşsizlik}

Umumiyetle işsiz denildiği zaman ilk hatıra gelen, kabiliyetsizliğinden dolayı bir meslek edinememiş veya geçimsizliğinden bir iş bulamamış insan düşünülmekteydi. 19.asırda geçerli olan bu yaklaşım, artık çağımı dünyasının ve ülkemizin şartlarına uymamaktadır. Bu nedenle işsizlik kişisel değil, sosyal bir sorundur. Yüz binlerce, bazen milyonlarca insan çalışma arzu ve iktidarında olsa da işsiz kalabilmektedir (Zaim, 1997, 169-173).

Bir ülkede çalışabilecek durumda olan ve çalışmak isteyen kişilerin bir bölümünün işinin olmaması durumu işsizlik olarak tanımlanmaktadır (Ünsal, 2003, 12). Diğer bir tanıma göre İsssizlik, üretimin olmazsa olmaz unsuru olan işgücünün kullanılmaması durumudur (Biçerli, 2004, 1).

TÜİK'in tanımlamasına göre ise işsiz, referans dönemi içinde istihdam halinde olmayan (kâr karşıllı̆̆ı, yevmiyeli, ücretli ya da ücretsiz olarak hiç bir iște çalışmamıș ve böyle bir iş ile bağlantısı da olmayan) kişilerden iş aramak için son üç ay içinde iş arama kanallarından en az birini kullanmış ve 15 gün içinde işbaşı yapabilecek durumda olan tüm kişiler işsiz nüfusa dahildir (TÜİK, 2010).

\subsection{Türkiye'de İşgücü Piyasasının Özellikleri}

Türkiye'de işsizlik, daha çok hızlı nüfus artışı, genç nüfusun payının yüksekliği gibi demografik unsurlarla ilişkilendirilmektedir. Bunun yanı sıra, iç göç ve kentleşmeyle birlikte ortaya çıan eğitim ve bölgesel dengesizlik eğilimleri de işsizliği arttırmaktadır. Türkiye gibi geçiş sürecini yaşayan bir ekonomide, piyasa ekonomisi mantığının rekabet kavramı ile desteklenememesi, özel sektör yatırım seviyesinin yetersizliği gibi nedenler işsizliğin yapısal bir sorun olarak ortaya çıkmasına neden olmaktadır (Uyar, $2008,50)$.

Türkiye, günümüzde "Demografik Geçiş Dönemi" olarak ifade edilen ve hızı giderek düşmekle beraber nüfus artışının devam ettiği süreci yaşamaktadır. Hızlı nüfus artışı ve kırdan kente göç ile birlikte kentlerde işgücü artmakta, fakat sanayi ve hizmetler sektörünün sınırlı yapısının bu artışa karşılık verememesi, işsizlik meydana getirmekte ve formel sektörde iş bulamayan işgücünün enformel sektöre kaymasına neden olmaktadır (Tokol, 2000, 115).

Sanayileşmede hedeflenen düzeye ulaş1lamaması, tarım toplumunun sürmesi ve hızlı artan genç nüfusun istihdamını sağlayacak yatırımların yapılamaması gibi nedenlerle işsizlik yapısal bir nitelik taşımaktadır. 
Türkiye'de işsizliğin bu yönü ile faktör dengesizliğinden kaynaklandığ $\breve{1}_{1}$ söylenebilir (Uyar, 2008, 57). Türkiye'de istihdam yaratmayan, aksine işsizliğin arttığ 1 bir büyüme sürecinden bahsedilir olmuştur (Hiç, 2009, 41). Ülkemizde işgücü piyasasında; bir taraftan gençlerin ve kadınların düşük işgücüne katılım ve istihdam oranları dikkat çekerken, diğer taraftan da özellikle gençler arasında, genel işsizlik oranından daha yüksek ve uzun süreli işsizlik oranları ile karşılaşılmaktadır. Bu nedenle günümüz sorunlarından biri de bu kesimlerin, işgücü piyasası ile bağlarının arttırılarak hızla istihdama hazır hale getirilmeleridir (Işı̆̆ıç̧ok, 2009, 215).

1950'lerde başlayan işgücüne katılma oranındaki düşmenin altında, tarım istihdamının azalması ve kırdan kente göç olgusu yatmaktadır. Kırdan kente göç ile birlikte, kırda işgücü içinde yer alan kadınlar kentte işgücü dışında görünmektedir. Diğer taraftan, kentlerde işlerin belirli beceriler gerektirmesi buna karşın kadınların eğitim düzeyinin düşüklüğü işgücü dışında kalmayı kalıcı hale getirmektedir. Çalışabilir yaştaki nüfusun yaklaşık yarısının üretime katılmaması, üreten kesimin giderek daha fazla kişiyi geçindirmek zorunda kalmasına ve üretime katılım sonucu elde edilen gelirin de daha fazla kişi arasında paylaşılmasına neden olmaktadır (İŞKUR III. Genel Kurul Raporu, 2005, 3).

\section{2..1. Türkiye'de İsssizlik Durumu}

Türkiye Cumhuriyetinin kurulduğu 1923 yılında 5 milyon 31 bin kişi istihdamda iken, 1960 yılında 11 milyon 259 bin, 1970 yılında 13 milyon 33 bin, 1990 yılında 18 milyon 541 bin, 2000 yılında 21 milyon 580 bin kişi ve son olarak 2009 yıl sonu hane halkı işgücü araştırması sonuçlarına göre, 25 milyon 537 bin işgücünden istihdam edilenlerin toplam sayıs1 22 milyon 108 bin kişiye ulaşmıştır. İ̧̧sizlik oranının yüksekliği ve işgücüne katılım oranının düşüklüğü göz önüne alındığ 1 zaman aslında bu artışın çok düşük oranda bir artış olarak gerçekleştiği görülmektedir (Bayhan, 2007, 10). Ülkemizde İşgücüne katılım oranının düşüklüğü göze çarpmakta olup, işgücüne katılma oranı o ülkenin sosyo-ekonomik yapısı ile yakından ilgilidir. İşü̈cüne katılma oranı ne kadar düşükse bunun karşılığında bağımlı nüfus o kadar yüksek olacaktır. Bağımlı nüfus kavramı işgücüne katılma kavramının tersi olup, d1şında kalanları belirtir (Ergün, 2000, 5).

\section{Tablo 1}

Temel işgücü göstergeleri (Ağustos 2010)

\begin{tabular}{|l|c|c|c|c|c|c|c|}
\hline \multirow{2}{*}{} & \multicolumn{2}{|c|}{ TÜRKIYYE } & \multicolumn{2}{|c|}{ KENT } & \multicolumn{2}{|c|}{ KIR } \\
\cline { 2 - 7 } & $\mathbf{2 0 0 9}$ & $\mathbf{2 0 1 0}$ & $\mathbf{2 0 0 9}$ & $\mathbf{2 0 1 0}$ & $\mathbf{2 0 0 9}$ & $\mathbf{2 0 1 0}$ \\
\hline Kurumsal olmayan nüfus (000) & 70639 & 71440 & 48793 & 49216 & 21846 & 22224 \\
\hline 15 ve daha yukarı yaştaki nüfus (000) & 51789 & 52645 & 36282 & 36615 & 15507 & 16030 \\
\hline İşgücü (000) & 25537 & 26166 & 16879 & 17279 & 8657 & 8887 \\
\hline İstihdam (000) & 22108 & 23195 & 14095 & 14856 & 8013 & 8339 \\
\hline İşsiz (000) & 3429 & 2971 & 2784 & 2423 & 644 & 548 \\
\hline İşgücüne katılma oranı (\%) & 49,3 & 49,7 & 46,5 & 47,2 & 55,8 & 55,4 \\
\hline İstihdam oranı (\%) & 42,7 & 44,1 & 38,8 & 40,6 & 51,7 & 52,0 \\
\hline İşsizlik oranı (\%) & 13,4 & 11,4 & 16,5 & 14,0 & 7,4 & 6,2 \\
\hline Tarım dişı işsizlik oranı (\%) & 17,0 & 14,5 & 17,0 & 14,5 & 17,2 & 14,1 \\
\hline Genç nüfusta işsizlik oranı(1)(\%) & 23,5 & 21,1 & 27,8 & 25,6 & 15,1 & 12,7 \\
\hline İşgücüne dahil olmayanlar (000) & 26252 & 26478 & 19402 & 19336 & 6850 & 7143 \\
\hline
\end{tabular}

(1) 15-24 yaş grubundaki nüfus

Kaynak: TÜİK Hanehalkı İşgücü Araştırmast, http://www.tuik.gov.tr (Temmuz, Ağustos, Eylül 2010 )

http://www.tuik.gov.tr/PreHaberBultenleri.do?id=6355, Erişim (29.11.2010) 
İşsizliğe ilişkin rakamlar, Türkiye'de genç işsizliğinin çok önemli bir sorun olduğunu göstermektedir. 15-24 yaş grubunda yer alan gençler Türkiye'de işsizlik sorunundan en fazla etkilenen yaş grubu olmaktadır. Türkiye'nin genç bir nüfus yapısına sahip olması nedeniyle genç nüfusta işsizlik oranı 23,5 ile genel işsizlik oranının iki katına yakındır.

İşsizliğin yapısal olması yanında, işsizliğin genç işsizliği olarak ortaya çıkması sorunun ciddiyetini daha da arttırmaktadir. Bu açıdan, eğitim sisteminin piyasanın ihtiyaçlarına göre düzenlenmesi, iş arayan gençlere iş bulmada yardımcı olunması ve mesleki becerilerini arttıracak yeni eğitim imkânlarının sağlanması gibi maliyetli olan aktif istihdam politikalarının uygulanmasına gerek duyulmaktadır (Uyar, 2008, 59).

1980'lerden bu yana dünya ekonomisinde, uluslararası işbölümünde ve egemen iktisat politikalarında gerçekleşen değişim sonucu ekonomik büyümenin istihdam yaratma etkisi zayıflamış, istihdam istikrarsızlaşmış ve yapısal işsizlik en önemli toplumsal sorun haline gelmiştir. Eylül/ Ekim 2008'de ortaya yüzüne çıkan küresel krizin en ağır toplumsal faturası da hızla tırmanan işsizlik oranları olmuştur. 2009'da Türkiye, gerek genel işsizlik oranının, gerekse genç işsizlik ve eğitimli genç işsizlik oranının dünya'da en yüksek olduğu ülkelerden biri olmuştur (Mütevellioğlu v.d. 2010, 208). Dünya'da olduğu gibi, ülkemizde de finansal ekonomik krizle birlikte işsizlik daha da artmıştır (Yavuz, 2010, 10).

2001 y1lından itibaren alınan tedbirlerle bankaların bünyesi sağlamlaştırılmıştır (Hiç, 2009, 40). Türkiye'de hiçbir banka iflas etmediği gibi, bankaların hepsi gerek 2008 yılı için gerekse 2009 yılının ilk 6 aylık dönemi için kar açıklamıştır. Dolayısıyla, Türkiye'de bir finans krizi olduğundan söz etmek doğru olmayacaktır. Ancak ülkemizde sanayi krizi, reel sektör krizi yaşanmaktadır (Yavuz, 2010, 10).

Türkiye'de nüfus artış hızı hala oldukça yüksek olduğu, özellikle çalışmayan bağımlı nüfus oranının artış gösterdiği görülmektedir. Nüfus artış hızı ile doğru orantılı iş ya- ratma kapasitesinde yeterli başarının yakalanamadığı, işgücüne her yıl katılan nüfusa istihdam yaratmada geri kalınmıştır. İş bulamama nedeniyle işgücü katılım oranları giderek büyük bir sorun haline gelmekte olup, bu noktada iş danışmanlığı hizmetinin önemi ortaya çıkmaktadır (Euroguidance, 2008, 159).

\subsection{2. İs Danısmanlığ 1}

Kişilerin özellikleri ile mesleklerin gerektirdiği nitelik ve şartları karşılaştırarak, bireyin istek ve durumuna en uygun işi seçmesi, işe yerleştirilmesi ve işe uyumunun sağlanması ile ilgili sorunların çözümüne sistemli olarak yardım edilmesi sürecidir (ISSKKUR, www.iskur.gov.tr, 15.11.2010). Uluslararas1 Çalışma Örgütü danışmanlık hizmetlerini sadece istihdam boyutu ile değil, insan kaynaklarının eğitimi, kariyeri, mesleki gelişimi ve emek piyasaları hakkında bilgilendirilme süreci olarak görmektedir (ILO, 2000, 88. Session). İş danışmanlığı, sadece ülkenin insan kaynağının etkinliğini değil, aynı zamanda işgücünü yetiştirmeye ve istihdam edilebilirliğini kolaylaştırmaya yönelik olarak verilen hizmetlerde kullanilan kaynaklarında, etkin ve doğru şekilde değerlendirilerek, amacına hizmet etmesini sağlayıcı bir fonksiyona sahiptir (Karagülle, 2008, 66).

İș danışmanlık hizmetleri aktif istihdam politikaları içerisinde 10-30 kat daha düşük maliyetlere sahip olmasından dolayı tercih edilmektedir (Biçerli, Çalışma Ek., 2007, 502). Maliyetlerin bu kadar düşük olmasından dolayı ülkelerde, iş danışmanlı̆̆ 1 ve işsizlerin izlenmesi programları yoğunlaşmış ve aktif istihdam programları içerisinde önemli bir yer almıştır (Forslund, 2008, 32).

Danışman, yardıma gereksinimi olan iş arayanlara, kendi özelliklerini tanıyıp değerlendirmelerine, bu özelliklere uygun meslek ya da iş seçeneklerini ya da yeni bir meslek edinmek için mevcut eğitim olanaklarını tanımaları için yol gösterir (İŞKUR, İşlemler El Kitabı, 2010). İş danışmanlığı hizmetlerinden sadece var olan işsizlerin değil, işinden memnun olmayanların, meslek seçiminde kararsız kişilerin ve mesleğini değiştirmek isteyen 
yetişkinlerin faydalanabilmeleri imkanı verilmektedir. İş danışmanlığı hizmetleri, genelde kamu istihdam bürolarının sorumluluğunda olmakla birlikte, aralarında Türkiye'nin de bulunduğu pek çok ülkede bu amaçla özel istihdam büroları da kullanılmaktadır (Biçerli, Çalışma Ek., 2007, 501). Danışmanlık hizmetleri özellikle gelişmiş ülkelerde internet üzerinde de yapilırken, gelişmekte ve az gelişmiş olan ülkelerde ise daha çok yüz yüze yapılması tercih edilmektedir (Micklewright, 2005, 6).

Meslek seçme aşamasında bulunan gençler, meslek veya iş edinmek, meslek veya iş değiştirmek, mesleğinde ilerlemek, mesleğini veya işini değiştirmek isteyen, iş bulmakta güçlükleri olan kişileri kapsayan bu hizmet, Türkiye'de ISSKUUR bünyesinde kurulan iş ve meslek danışmanlığ tedir. İŞKUR'un bu hizmetlerinden tüm vatandaşlar bedelsiz olarak faydalanabilmektedirler (Karagülle, 2007, 32). 2008 Ekonomik kriz sonrasında hem ülkemizde hem de birçok ülkede, iş arama yardımı ve iş danışmanlığı hizmetlerinin kapsamı genişletilmiş, kişiye özel yardım veya iş arayanlara kariyer danışmanlığı sunmak yoluyla iş arama yardımlarının yoğunluğu artırılmıştır (TİSK, 2009).

\section{IŞ DANIŞMANLIĞI UYGULAMALARI}

\subsection{Bazı Ülkelerde İş Danışmanlığı}

İş danışmanlık hizmetleri, çoğu ülkelerde aktif istihdam politikaları içerisinde gelir destekli politikalar ile birlikte önemli bir yer tutmaktadır (ILO, 2010, 56). OECD'nin 2001 y1lı verilerine göre Avustralya, Kanada, Japonya, Norveç ve ABD'nin aktif istihdam politikaları içinde en fazla kaynak, eşleştirme ve danışmanlık hizmetlerine ayrılmıştır (Biçerli, Çalışma Ek., 2007, 502). Küresel krizle beraber neredeyse tüm ülkeler, kamu istihdam hizmeti kurumlarının sunduğu iş arama yardımı ve danışmanlık hizmetlerinin kapsamını genişletmişlerdir (örneğin, Avusturya, Belçika, Fransa ve İngiltere). Yine pek çok ülke, iş arayan kitleye yeterli hizmet sunabilmek için kamu istihdam hizmeti çalı- şanlarının sayısını artırmıştır. Avustralya, Çek Cumhuriyeti, Danimarka, Finlandiya, İrlanda ve İngiltere'de olduğu gibi pek çok ülke aynı zamanda, kişiye özel yardım veya iş arayanlara kariyer danışmanlığı sunmak yoluyla iş arama yardımlarının yoğunlugunu da artırmıştır (TISSK, 2009). Ülkelerin bir kısminda yüksek yoğunluklu, bir kısmında ise düşük yoğunluklu, bazılarında ise her ikisi yoğunlukta danışmanlık hizmetleri verilmektedir (Breunig, 2002, 18). Yapilan araştırmalarda, yüksek yoğunluklu danışmanlık hizmetlerinin daha fazla etkili olduğu görülmüştür (Gerard v.d., 2001, 36).

İngiltere'de iş danışmanlığı için, “İş Merkez Noktası " (Jobcentre plus) olarak hizmet verilmektedir. Bu noktalarda danışanlara geniş hizmetler ve bilgiler sunulmaktadır. Örneğin; hizmetler hakkında bilgilendirme, yardımlar, ödemeler, iş arama ve eşleştirme, işsizlik sigortası ve diğer aktif istihdam politikaları hakkında danışmanlık hizmetleri sayılabilir. İngiltere'de işsizlik ödeneği alanların danışmanlık hizmeti alması zorunludur (www.direct.gov.uk, 29.11.2010). Özel istihdam bürolarının da aracılık hizmeti verdiği İngiltere'de, kamuya bağlı iş merkezlerinin her birinde ortalama 30'a yakın personel çalışmakta ve toplamda 1000 'in üzerinde büro ile hizmet verilmektedir. Bu bürolar eşleştirme ve danışmanlık hizmetlerinin yanı sıra işsizlik sigortasının ve diğer aktif istihdam politikalarının yürütülmesi işlerini de yapmaktadırlar (Karagülle, 2007, 44). İngiltere'de yapılan bir çalışmada, danışmanlık hizmetlerinin kısa vadede işsizlik süresini önemli ölçüde kısalttığ1 tespit edilmiştir (Biçerli, Çalışma Ek., 2007, 502). Restart adlı işsizlerin katılımının olduğu programda yapılan araştırma neticesinde, hem kısa hem de uzun vadeli işsiz olan erkek katılımcıların işsizlik oranlarının \%5-15 arası azaldığı, kadınlar üzerinde ise sadece kısa vadede olumlu etkilerinin olduğu tespit edilmiştir (Borland, 2003, 5). Bununla birlikte, bazı ülkelerde (Norveç) danışmanlık hizmetlerine kadınların olumlu tepki vermediği ortaya çıkmıştır (Blasco, 2010, 29).

Ekonomik kriz sonrası İngiltere İstihdam 
Kurumu'na ilave personel alınmıştır. İş arama eğitimi ve yardımları için daha fazla kaynak sunumu, toplu işten çıkarma yapan işletmelere, çoklu işten çıkarmalardan etkilenen topluluklara, yeni işten çıkarılmış ve başka bir iș bulmasının önünde ciddi engelleri olanlara veya 6 aydan fazla işsiz kalanlara ilave destekler sunulması yoluna gidilmiştir (TISKK, 2009).

Amerika'da iş danışmanlığ 1 (Job Adviser) adı altında hizmet sunulmaktadır. İş danışmanlığı hizmetinde kişilerin durumlarına en uygun iş için araştırma yapılabilmekte, özgeçmiş hazırlama konusunda destek verilmekte ve aynı hizmetlere online olarak ulaşılabilmektedir (www.job-adviser.com, 29.11.2010). Amerika'da ekonomik kriz sonrası eyalet düzeyindeki istihdam hizmetleri yoluyla sunulan kariyer danışmanlığı ve iş arama yardımlarına sağlanan fon katkıları da artırılmıştır (TİSK, 2009).

Almanya Çalışma Kurumu'nun, ülkede etkinliğini arttıran en önemli faktörlerden birini, danışmanlık görevlerini üstlenmesi oluşturmaktadır (Karagülle, 2007, 48). Almanya'da danışmanlar işsizleri, işçileri, işverenleri; iş piyasasının durumu, meslekler, mesleki eğitim olanakları ve bu konulardaki çalışmalar hakkında bilgilendirmektedir. İşsizlik sigortası alanların danışmanlık hizmeti alması zorunludur. Kriz sonrası erken yerleştirme görüşmeleri ve danışmanlık hizmetleri sağlamak için danışman sayısı arttırılmıștır. (TİSK, 2009)

İş ve meslek danışmanlığ 1 konusunda gelişmiş bir sisteme sahip olan Finlandiya Kamu İstihdam Kurumu, bünyesinde istihdam ettiği 250 psikolog ile kamu istihdam bürolarının 2/3'ünde danışmanlık hizmeti vermektedir (Karagülle, 2007, 47). Finlandiya'da iş arama faaliyetlerinde artırıma gidilmiş ve iş arayanların daha erken değerlendirilerek, bir iş planı geliştirilmesi, Kamu İstihdam Hizmetleri çalışanlarına geçici olarak daha çok kaynak ayrılması, daha önceleri Kamu İstihdam Kurumu'na kayıt olması mecbur tutulmayan ancak açığa alınmış işçilere yönelik mevcut iş arama yardımının kapsamının genişletilmesi ve danışmanlık hizmeti sunulması şartı getirilmiştir (TISK, 2009). Bir İskandinav ülkesi olan İsveç'te ise, 2001 yılında hem iş danışmanlığ 1 hem de işsizlerin izlenmesi (monitoring) faaliyetlerine dayanan (the activity guarantee) adlı program başlatılmıştır. Gelir destekli olan bu programla daha çok uzun süreli işsizlerin coğrafi hareketliliği hedeflenmiştir (Forslund, The Swedish.., 2004, 3)

Belçika'da ekonomik kriz sonrası federal düzeyde; 20 'den fazla işçi çalıştıran ve toplu işten çıkarma yapan tüm şirketlerde işçilerin desteklenmesi, iş arama yardımı ve kariyer danışmanlığı hizmetleri sunma amaçlı bir birim oluşturulmuştur. Vagon Bölgesi'nde iş arama desteğinin önceki geçici işçileri de kapsaması, Flaman Bölgesi'nde kamu istihdam servislerine daha fazla eleman alınması ve önceki geçici işçilere dönük yardımlar yapılması sağlanmıştır (TISK, 2009). Fransa'da ise, 2001 Temmuz ayında işsizlik politikalarında reform sayılacak bir program başlatılmiştır. Bu reformun önemli bir parçası olan Kamu İşsizlik Ajansı, işsizleri desteklemek amaciyla program doğrultusunda faaliyetlerini gözden geçirerek, işsizlere daha fazla ve yoğun (birebir ilgilenerek) danışmanlık hizmetlerinin sağlanmasını hedeflemiştir (Crepon, 2004, 1).

Hollanda'da ise, 7 adet istihdam bürosunda yoğunlaşan is danışmanlığı hizmetleri sayesinde diğer bürolara oranla iş bulma sürelerinin kısaldığ 1 ve iş bulma oranlarının \%15 arttığ1 gözlenmiştir (Gorter, Cees, and Guyonne R. J. Kalb, 1996, 596). Hollanda ile ilgili Gerard'ın yaptığı başka bir çalışmada ise, hem işsizlik sürelerinin, hem işsiz sayısının azaldığı, hem de işsiz olanların kayıt dışından kayıtlı çalışmaya doğru geçiş yaptıkları ortaya çıkmıştır (Gerard v.d., 2000, 2).

Meksika'da ekonomik kriz sonrası iş eşleştirmesi ve iş arama yardımını içeren kamu istihdam hizmetleri için kullanılan kaynak fonunda artırım, Mart 2008'de iş arama ve eğitim amacıyla bir internet portalı'nın oluşturulması ve özürlü işçilerin iş bulmasına yardım etmek için bir programın başlatılması 
ile gerçekleştirilmiştir (TİSK, 2009).

\subsection{Türkiye'de İş Danışmanlı̆̆ı Faaliyetleri}

Ülkemizde iş danışmanlığ hizmetini, 4904 sayılı Türkiye İş Kurumu Kanunu'nun $3 /$ c ve $9 /$ b maddeleri esasları ve yurtiçinde işe yerleştirme hizmetleri hakkında yönetmeliğin 12.maddesi ve Türkiye İş Kurumu işgücü uyum hizmetleri yönetmeliği 30.maddesi gereği ISŞKUR uygular veya uygulatır (T.C. Resmi Gazete 25/04/2009 Say1sı: 27210) ${ }^{x} .2009$ y1lından itibaren Türkiye İş Kurumu'nun tüm İl/Şube Müdürlüklerinde iş danışmanlığ 1 hizmeti verilmeye başlanmıştır.

İş danışmanlığ İŞKUR tarafından uygulanan aktif işgücü piyasası programları arasinda yer almaktadır (Karabulut, 2007, 34). Türkiye'de özel sektörde kariyer danışmanlığı, iş koçluğu olarak adlandırılan danışmanlık hizmetleri iş danışmanlığ 1 olarak sadece ülkemizin tek kamu istihdam kurumu olan İŞKUR tarafından ücretsiz olarak sunulmaktadır.

Danışmanlık hizmetlerinden faydalanmada gönüllülük esas olmakla birlikte iş arayanlar bizzat kuruma gelerek ya da internet üzerinden randevu alarak ücretsiz olarak bireysel danışmanlık hizmetinden yararlanabilmektedirler. İş arayanlar İŞKUR'a kayıtları esnasında da iş danışmanlığ 1 görüşmesine yönlendirilebilmektedir. Danışmanlık esnasında kişiler hakkında edinilen bilgiler gizli tutulmakta, hiçbir nedenle başka kişi ve kurumlara verilmemektedir.

Herhangi bir sınırlama olmaksızın isteyen herkes ISSKUUR'un danışmanlık hizmetlerinden yararlanabilmektedir. Bununla beraber iş danışmanlığı hizmetinden faydalanabilecek olanlara bakıldığında (İSKKUR, www.iskur.gov.tr, 15.11.2010);

- İlk defa iş piyasasına giren ve henüz mesleği olmayan gençler ve yetişkinler, uzun süre işsiz kalanlar,

- İşverene dört ya da dörtten fazla gönderildiği halde işe giremeyenler,

- Özelleştirme, işyeri kapanması veya ekonomik durgunluk nedeniyle işini kaybetmiş olan ve bu nedenle işsizlik ödeneği alan, becerilerini geliştirmek isteyen, yeni bir iş bulmada ya da mesleğini değiştirme ve uyum sağlamada zorluğu olanlar,

- Mevcut mesleki eğitim imkânları hakkında bilgi isteyenler,

- Güncelliğini yitirmeye başlayan mesleklerde istihdam edilen ve istihdam edilebilirliğini artırmak için ek bir mesleki eğitime ihtiyacı olabilecek kişiler,

- Herhangi bir mesleği olmayıp, işgücü yetiştirme kursuna katılmak isteyenler,

- Çalışabilecekleri potansiyel işlerin nasıl bulunacağı hakkında bilgi isteyenler,

- İş aramada yönlendirmeye ihtiyaç duyan ve bu nedenle iş arama becerileri eğitiminden yararlanabilecek kişiler,

- Kendi işini kurmak isteyenler, iş danışmanlığı hizmetinden yararlanabilirler.

Danışmanlık hizmetleri pratik bilgileri, iş hakkında yönlendirmeyi ve iş başvuru teknik ve yöntemleri gibi konuları kapsamaktadır (Alabaş, 2007, 60). İŞKUR'da iş danışmanı olarak görev yapan personel, danışanların kendilerini tanımalarına, edindikleri bilgileri kendilerinde var olan nitelik ve şartları, iş veya mesleklerin gerektirdiği nitelik ve ko-

\footnotetext{
* MADDE 12 - (1) Kurum; mesleklerin gerektirdiği nitelik ve şartlar ile özürlü ve eski hükümlülerin özelliklerini göz önünde bulundurarak; bunların istek ve durumlarına en uygun iş ve mesleği seçmesi, seçtiğ i meslekle ilgili eğitim imkânlarından yararlanması, işe yerleştirilmesi ve işe giriş sürecinde mesleki eğitim, danışmanlik ve rehabilitasyon programları veya işyerinde mesleki eğitim programları uygular/uygulatır, iş danışmanlığı hizmeti verir/verdirir.

MADDE 30 - (1) Uygulanacak aktif işgücü programlarına esas olmak üzere sunulan iş ve meslek danışmanlığı hizmetleri; bireylerin ilgi ve yeteneklerine uygun iş ve mesleği seçmesi, seçtiği meslekle ilgili eğitim imkânlarından yararlanması, işe yerleştirilmesi ve işe uyumunun sağlanması amacıyla, doğrudan Kurum tarafından ya da Genel Müdürlükçe belirlenen esaslara bağlı olarak hizmet alımı yoluyla yürütülür.
} 
şullarla karşılaştırarak bir eğitime yönelme veya işyerine yerleştirilmelerine yardımcı olur.

Danışman, işsizlere iş piyasasına uygun bilgileri sunmakta, iş piyasasına yeni girecek gençlerin kariyer planlamasına yardımcı olmakta ve işsizlere diğer aktif tedbirlerin alınmasında, yol gösterici olmalarıyla çok önemli bir görev üstlenmektedir (Tiryaki, 2007, 36). Bir işe girmede, o işte çalışmaya devam etmede ya da ilerlemede engellerle karşılaşan kişilerin mesleki ve kişisel sorunlarını fark etmelerine ve iş ortamına daha iyi uyum sağlamak için planlar yapmalarına yardımcı olur (İSKUR, İşlemler El Kitabı, 2010).

İş danışmanları işyeri ziyaretleri ile işverenler ile temas kurarak, açık işler ve yerel düzeyde işgücü piyasası hakkında bilgi toplayıp, işsizleri alınan işgücü taleplerine yönlendirmektedirler. İs arayan ve/veya meslek seçme aşamasında olan kişilerin istihdam ve eğitim eylem planı oluşturmasına yardımcı olur. İstihdam eylem planının kullanılmasının amacı, danışanın en yakın zamanda iş bulması için desteklenmesidir (İŞKUR Model Ofis Kılavuz Kitapçı̆̆ Eki, 4.Bölüm).

İşsizlik sigortası alanlar, İŞKUR tarafından iş danışmanlığı görüşmesine davet edildiklerinde gelmek mecburiyetindedirler. Davete gelmeyenlerin geçerli mazeretleri olmadığında işsizlik ödenekleri davete gelmeme nedeniyle kesilmektedir. İşsizlik ödeneği davete gelmeme nedeniyle kesilenler, daha sonra İSKUR'a geldiklerinde geç geldikleri gün kadar hak kaybına uğramaktadirlar.

Kurum 2009 yılında iş ve meslek danışmanlığ 1 hizmetlerinden yararlanan katılımc1 sayısını \%10 arttırarak 169.976 kişiye ulaşmayı hedeflemiş, 2009 yılında iş ve meslek danışmanlığ 1 hizmetlerinden yararlanan kişi sayısı 211.456 kişi olarak gerçekleşmiştir. İş danışmanlığ1 eğitimi düzenlenerek bu alanda görev yapan personel sayısının, hizmetin yürütüldüğü il/şube sayısının ve hizmetin tanınırlığının artması nedeni ile hedef aşılmıştır (İSKUR 2009 Faaliyet Raporu, 2010, 72).

\subsubsection{Bireysel görüsmeler}

İş arayanlar Kuruma internet üzerinden üye olup bireysel danışmanlık randevusu alabilmektedirler. İş danışmanı randevuyu onayladığında belirlenen gün ve saate görüşme gerçekleşmektedir. İş danışmanları bireysel danışmanlık hizmeti yanında il/şube müdürlükleri tarafından açlacak olan işgücü yetiştirme kurslarına kursiyer seçiminde görev almaktadırlar.

İş arayanlar Kuruma ilk geldiğinde yap1lan bireysel danışmanlık görüşmesinde, kişinin iş bulabilmesini kolaylaştıracak nitelikleri tespit edilmektedir (Tiryaki, 2007, 35). İstihdam eylem planı hazırlanarak durumları belli aralıklar ile takip edilmekte, iş görüşmelerine yönlendirilmekte, durumlarına uygun açık işlere yerleştirilmeleri sağlanmakta ve işsizlerin iş ile buluşması gerçekleştirilmiş olmaktadır (İŞKUR, İşlemler El Kitabı, 2010). Bu çerçevede Yalova'da 2009 yılında 92 kişi, 2010 yılında 272 kişi bireysel iş danışmanlığı hizmetinden faydalanmiştır.

\subsubsection{Grup görüsmeleri}

Kurum hizmetlerinin tanitıminın yapıldığı grup görüşmesinde iş danışmanları, cezaevi ve islah evlerinde kalan genç ve yetişkinleri ceza sürelerini tamamladıklarında sahip olacakları haklar konusunda bilgilendirerek, iş arama tekniklerinin geliştirilmesine yönelik eğitimler vermektedirler.

Kurumca yapılmakta olan iş arama becerilerinin geliştirilmesine yönelik çalışmalarda, Kuruma başvuran ve iş arama sürecinde olan yetişkinlere, mesleki eğitim merkezi, meslek lisesi ve üniversite son sınıf öğrencileri ile askerlik görevini tamamlamak üzere olan er ve erbaşlara (Karabulut, 2007, 86) yönelik, kurum hizmetlerinin tanıtıldığ 1 ve iş arama becerilerinin geliştirilmesine yönelik seminer, eğitim ve benzeri çalışmalar gerçekleştirmektedirler. Bu çalışmalarda, işveren talep ve beklentileri, işe başvuru teknikleri, iş talep formu, takdim mektubu, tanıtım kartı, öz geçmiş hazırlama, iş görüşmesine hazırlık ve mülakat gibi konular üze- 
rinde durulmaktadır (İŞKUR İşlemler El Kitabı 6 Kısım, 2. Bölüm).

İş Arama Becerileri Eğitim Programı iş arayanlara kendi girişimleri ile iş bulmaları için iş arama becerilerinin ve yaklaşımlarınin geliştirilmesinde rehberlik etmek ve onları yönlendirmek amacıyla tasarlanmıştır. Kurumun iş danışmanları iş arayanla birlikte aşağıda belirtilen konular üzerinde eğitim çalışması yaparlar (İŞKUR İşlemler El Kitabi 10.Bölüm).

- İş arama sürecinin planlanması

- İş arama becerilerinin etkinliğinin artırilmasi

- İşücü piyasası ve meslek bilgileri sağlanmasi

- İş görüşmesi becerilerinin kazandırılmas1

- İş arama faaliyetlerine özendirme

- Öz sayginin ve özgüvenin geliştirilmesi

- İşe girme yolları

İş Arama Becerileri Eğitim Programı'nın amaçlarına bakacak olursak (İSKKUR İşlemler El Kitabı 10.Bölüm);

- İș arayanlara işgücü piyasası ve açık işler hakkında bilgi edinmelerine ve istihdam edilebilmeleri için açık işlerin kaynaklarını belirlemelerine ve iş arama becerilerini geliştirmelerine yardımcı olmak,

- Katılımcıların güçlü ve zayıf yönlerini değerlendirmelerine ve önceden sahip oldukları beceri, bilgi ve deneyimlerini geliştirmeyi öğrenmelerine olanak sağlamak,

- Katılımcıların, hangi işlerin yeteneklerine ve isteklerine uyduğunu belirlemelerine yardımcı olmak,

- Katılımcıların yerel işgücü piyasasını, firmaların işe alma yöntemlerini ve işverenin gereksinim ve görüş açılarını anlama yeteneğini geliştirmek,

- Fabrika ya da işyerinin kapatılması ve başka nedenlerle işsiz kalan katılımc1nın sarsılmış olan özsaygısını ve özgüvenini yeniden kazandırmaktır.
Kurum 2009 yılında iş arama becerileri hizmetlerinden yararlanan katılımcı sayısını $\% 10$ arttırarak 97.750 kişiye ulaşmayı hedeflemiştir. Bununla birlikte, 2009 y1lında iş arama becerileri hizmetlerinden yararlanan kişi sayısı 129.365 kişi olarak gerçekleşmiştir. $\mathrm{Bu}$ alanda görev yapan personel sayısı ile hizmetin yürütüldüğü il/şube müdürlüğü sayısının artması nedeni ile hedef aşılmıştır (İSKUR 2009 Faaliyet Raporu, 2010, 72). Yalova İl Müdürlüğü olarak 2009 yılı içerisinde 900 kişiye 2010 yılında 1284 kişiye İş Arama Becerileri Eğitimi verilmiştir.

\section{3. İŞ DANIŞANLIĞI HIZZMETi ÜZERİNE BíR ALAN ARAŞTIRMASI}

\subsection{Araştırmanın Amacı}

İş danışmanlığ ${ }_{1}$ hizmetinin tanınırlığını ölçmek, iş arayanların iş danışmanlığı hizmetine olan bakış açılarını belirlemek ve bu veriler ışığında iş danışmanlığının işsizlik sorununun çözümündeki katkılarını ortaya koymaktır.

\subsection{Araştırmanın Hipotezi}

Çalışmanın hipotezi, iş danışmanlığı hizmetinin işsizlikle mücadelede önemli katk1ları olmasına rağmen hizmetin farkındalık düzeyinin düşük olduğu ve işsizlerin danışmanlık hizmetine ihtiyacı olduğu halde iş danışmanlığ1 hizmetinin tanıtımının yeterli düzeyde olmaması nedeniyle iş arayanlar tarafından bilinmediğidir.

\subsection{Araştırmanın Modeli}

Araştırmamızda anket yöntemi kullanılmiş ve katılımcılara 20 soru yöneltilmiştir. Bazı soruların alt maddeleri ile 33 soru olmuştur. İlk 10 sorudan dört tanesi demografik özellikleri belirlemeye yönelik olup geri kalan altı tanesi ise istihdam durumu ve İŞKUR hizmetleri konusundaki bilgi düzeylerini ölçmeye yönelik olduğundan iş danışmanlığ 1 görüşmesi öncesinde uygulanmıştır. Son 10 soru ise iş danışmanlı̆̆ hizmeti sonrası görüşleri belirlemeye yönelik sorular olduğundan danışmanlık görüşmesinden sonra uygulanmiştır. 


\subsection{Araştırmanın Evreni ve Örneklemi}

Araştırmamızın evreni İŞKUR'a kayıtlı iş arayanlardır. Araştırmamızın örneklemi ise Yalova ilinde ikamet edip, iş danışmanlığ1 hizmetini talep eden işsizlerden oluşmaktadır. Araştırmamıza 2010 yılı içerisinde iş danışmanlığ 1 hizmetinden faydalanan 272 iş arayan içerisinden $26^{\prime}$ sı erkek $86^{\prime}$ s 1 kadın olmak üzere toplamda 112 kişi katılmıştır. Çalışmamız SPSS programında güvenilirlik testine tabi tutulmuş ve çıkan Cronbach Alfa oranı eşik olan 0,70 'in üzerinde, 0,823 olarak geçekleşmiştir.

\section{Tablo 2}

Güvenilirlik Katsayısı

\begin{tabular}{|c|c|}
\hline Cronbach's Alpha & N of Items \\
\hline, 823 & 33 \\
\hline
\end{tabular}

\subsection{Anket Sonuçlarının Değerlendirilmesi}

Anketin ilk dört sorusunda katılımcıların demografik özellikleri tespit edilmiştir. Buna göre;

\section{Tablo 3}

Yaş Bilgileri

\begin{tabular}{|l|c|c|}
\hline & Katılımcı Sayıs & \% Oran \\
\hline $15-18$ & 12 & 10,7 \\
\hline $19-24$ & 45 & 40,2 \\
\hline $25-34$ & 46 & 41,1 \\
\hline $35-44$ & 8 & 7,1 \\
\hline $45-54$ & 1 & 9 \\
\hline Toplam & $\mathbf{1 1 2}$ & $\mathbf{1 0 0}$ \\
\hline
\end{tabular}

Katılımcıların 46 tanesi (\%41,1) 25-43 yaş arasında, 45 tanesi $(\% 40,2) 19-24$ yaş arasında, 12 tanesi $(\% 10,7) 15-18$ yaş arasında, 8 tanesi $(\% 7,1) 35-44$ yaş arasında 1 tanesi ise 45-54 yaş arasındadır. Ülkemizde genç nüfusta işsizlik yüksek oranlarda seyretmekte olup, iş danışmanlığ 1 hizmetinden faydalananlara bakıldığında da genelde 19-34 yaş grubu arasında yığılma olmuştur, bu durum ülkemizde yaşanan genç işsizliğin bir göstergesi konumundadır.

\section{Tablo 4}

Cinsiyet Bilgileri

\begin{tabular}{|l|c|c|}
\hline & Katılımcı Sayısı & \% Oran \\
\hline Erkek & 26 & 23,2 \\
\hline Kadın & 86 & 76,8 \\
\hline Toplam & $\mathbf{1 1 2}$ & $\mathbf{1 0 0}$ \\
\hline
\end{tabular}

Ankete katılan 112 katılımcinın 86 tanesi $(\% 76,8)$ kadın, 26 tanesi $(\% 23,2)$ erkektir. Anket yapılan dönem içerisinde genelde bayanların tercih ettiği mesleklerde eğitim kursları düzenlenmiş olduğundan, mesleki eğitim kurslarına katılmak için IŞKUR'a gelen kadınlardan, danışmanlık hizmeti alanların sayısı, iş aramak için İ̧SKUR'a başvurup danışmanlık hizmeti alan erkeklerin sayısının oldukça üzerinde çıkmasına neden olmuştur.

\section{Tablo 5}

Eğitim Durumu

\begin{tabular}{|l|c|c|}
\hline & Katılımcı Sayısı & \% Oran \\
\hline Okuryazar & 1 & 0,9 \\
\hline İlköğretim & 27 & 24,1 \\
\hline Lise ve Dengi & 40 & 35,7 \\
\hline Meslek Lisesi & 23 & 20,5 \\
\hline Önlisans & 13 & 11,6 \\
\hline Fakülte & 5 & 4,5 \\
\hline $\begin{array}{l}\text { Yüksek Lisans } \\
\text { ve Doktora }\end{array}$ & 3 & 2,7 \\
\hline Toplam & $\mathbf{1 1 2}$ & $\mathbf{1 0 0}$ \\
\hline
\end{tabular}

Katılımciların 40 tanesi $(\% 35,7)$ Lise ve dengi mezun, 27 tanesi (\% 24,1) İlköğretim mezunu, 23 tanesi $(\% 20,5)$ Meslek lisesi me- 
zunu, 13 tanesi $(\% 11,6)$ Önlisans mezunu, 5 tanesi $(\% 3,5)$ Fakülte mezunu, 3 tanesi $(\% 2,7)$ Yüksek Lisans ve Doktora 1 kişi ise okuryazardır. Genel eğitim durumuna bakıldığında herhangi bir mesleği olmayan düz lise mezunları ağırlıktadır. İş danışmanlığı alanların eğitim durumuna bakıldığında fakülte ve üzeri mezunların sayısının azlığ mektedir. Bunun nedeni olarak üniversite mezunlarının bir iş arama kanalı olarak İŞKUR'u daha az tercih etmesinden kaynaklandığını söyleyebiliriz.

\section{Tablo 6}

Medeni Durum

\begin{tabular}{|l|c|c|}
\hline & Katılımcı Sayısı & \% Oran \\
\hline Bekar & 66 & 58,9 \\
\hline Evli & 37 & 33 \\
\hline Eşi Ölmüş & 1 & 0,9 \\
\hline Boşanmış & 8 & 7,1 \\
\hline Toplam & $\mathbf{1 1 2}$ & $\mathbf{1 0 0}$ \\
\hline
\end{tabular}

Katılımciların 37'si evli (\%33), 66'sı bekar $(\% 58,9)$, 8'i $(7,1)$ boşanmıştır. Bir kişinin ise eşi ölmüştür. İş danışmanlığından faydalananlar genelde genç işsizler olduğu için bekarların çoğunluğu dikkat çekmektedir.

\section{Tablo 7}

Ne Zamandan Beri İş Arıyorsunuz?

\begin{tabular}{|l|c|c|}
\hline & Katılımcı Sayıs & \% Oran \\
\hline 1 Ay - 6 Ay & 44 & 39,3 \\
\hline 6 Ay - 1 Y1l & 34 & 30,4 \\
\hline 1 Y1l - 2 Y1l & 20 & 17,9 \\
\hline 2 Y1l - 3 Y1l & 8 & 7,1 \\
\hline 3 Y1l - 4 Y1l & 1 & 0,9 \\
\hline Dört Y1l ve Üzeri & 5 & 4,5 \\
\hline Toplam & $\mathbf{1 1 2}$ & $\mathbf{1 0 0}$ \\
\hline
\end{tabular}

Katılımciların 44 tanesi $(\% 39,3) 1$ ay- 6 ay arasında, 34 tanesi $(\% 30,4) 6$ ay- 1 yıl arasinda, 20 tanesi (\%17,9) 1 yil-2 yil arasinda, 8 tanesi $(\% 7,1) 2$ y1l-3 yil arasinda, 5 tanesi $(\% 4,5)$ dört yıl ve üzeri ve 1 tanesi ise 3 yıl- 4 yıl arasında iş aramaktadır. İş arama süresi genelde bir ay ile iki yıl arasında olmasina rağmen uzun süreli işsizlerde bulunmaktadır. Yapısal işsizlik sorununun yanında istihdam yaratmayan büyüme, iş arama süresinin gittikçe uzamasına neden olmaktadir.

\section{Tablo 8}

İş Arama Sürecinde Destek İhtiyacı Var mı?

\begin{tabular}{|l|c|c|}
\hline & Katılımcı Sayısı & \% Oran \\
\hline Evet & 101 & 90,2 \\
\hline Hayır & 11 & 9,8 \\
\hline Toplam & $\mathbf{1 1 2}$ & $\mathbf{1 0 0}$ \\
\hline
\end{tabular}

Katılımcıların 101 tanesi $(\% 90,2)$ iş arama sürecinde desteğe ihtiyacı olduğunu düşünüyor, 11 tanesi $(\% 9,8)$ ise desteğe ihtiyacı olmadığını düşünüyor. Danışanların çoğu iş arama yöntemleri, özgeçmiş hazırlama ve mülakat teknikleri konusunda bilgi eksikliği hissettiklerini ve ISSKUR'dan iş arama sürecinde danışmanlık desteği beklediklerini ifade etmişlerdir.

\section{Tablo 9}

İş Danışmanlığı Hizmetini Daha Önce Duydunuz mu?

\begin{tabular}{|l|c|c|}
\hline & Katılımcı Sayıs & \% Oran \\
\hline Evet & 60 & 53,6 \\
\hline Hayır & 52 & 46,4 \\
\hline Toplam & $\mathbf{1 1 2}$ & $\mathbf{1 0 0}$ \\
\hline
\end{tabular}

Katılımcıların 60 tanesi $(\% 53,6)$ iş danışmanlığ1 hizmetini daha önce duyduğunu belirtmiş, 52 tanesi ise $(\% 46,4)$ daha önce duymadığını belirtmiştir. İş danışmanlığı hizmetinin iş arayanlar tarafindan yeterli düzeyde bilinmediği görülmektedir. 


\section{Tablo 10}

İş Danışmanlığ 1 Hizmetini Nereden Duydunuz?

\begin{tabular}{|l|c|c|c|}
\hline & Katılımcı Sayısı & Evet & \% Oran \\
\hline İş danışmanlığı hizmetini internet'ten öğrendim & 60 & 31 & 51,7 \\
\hline İş danışmanlığı hizmetini TV'den duydum & 60 & 10 & 16,7 \\
\hline İs danışmanlığı hizmetini gazeteden öğrendim & 60 & 11 & 18,3 \\
\hline İş danışmanlığı hizmetini dergiden öğrendim & 60 & - & - \\
\hline İş danışmanlığı hizmetini radyodan öğrendim & 60 & 1 & 1,7 \\
\hline İş danışmanlığı hizmetini afiş, broşürlerden öğrendim & 60 & 3 & 5 \\
\hline İş danışmanlığı hizmetini diğer yerlerden öğrendim & 60 & 20 & 33,3 \\
\hline
\end{tabular}

İş arayanlar içerisinde iș danışmanlığg hizmetlerini bilen60 katılımcının genelde, iş danışmanlığ hizmetini internet, TV, gazete ve diğer yerlerden (eş, dost, arkadaş vb.) duyduğunu belirtmiştir. Gelişen teknolojinin ve yazılı basının kullanılması hizmetin tanınmasına katkı yapmaktadır. Hizmetin tanınırlığını arttırmada kullanılan araçlar içerisinde dergi, broşür ve radyonun yeterli düzeyde olmadığı görülmektedir.

İşsizler, iş ararken sırasıyla akraba ve tanıdık, İSKUR, gazete, İnternet ve iș yeri ziyaretlerini kullandıklarını belirtmişlerdir. İș arama kanallarından ilk sirada akraba ve tanıdık çıkması geçmiş alışkanlıkların hala devam ettiğini göstermektedir. İSKUR'un ikinci sırada kullanıldığı görülmekte olup bunun nedeni olarak İŞKUR'un İnternet or- tamında da hizmet sunmaya başlaması ile daha fazla işsize ulaştığı söylenebilir. İnternet günümüzde giderek artan oranda kullanılmaya başlanmıştır. Gazete ilanlarının işsizler tarafından takip edildiği görülmektedir. Yalova'da özel istihdam bürosunun olmaması, özel istihdam bürolarını kullanan sayısının düşük çıkmasının nedeni olarak gösterilebilir.

İşarayanlar ekonomik kriz ile birlikte say1sı artan meslek eğitim hizmetlerini ilk s1rada, işe yerleştirme aracılık hizmetlerini ikinci sırada ve işsizlik sigortası hizmetini ise üçüncü sırada bildikleri görülmektedir. İŞKUR'un iş danışmanlığı ve diğer hizmetlerinin ise, mesleki eğitim, eşleştirme ve ișsizlik sigortası hizmetlerine nazaran yeterli düzeyde bilinmediği görülmektedir.

\section{Tablo 11}

Bu Güne Kadar İş Ararken Hangi Yolları Kullandınız?

\begin{tabular}{|l|c|c|c|}
\hline & Katılımcı Sayısı & Evet & \% Oran \\
\hline İş ararken gazete ilanlarını kullandım & 112 & 48 & 42,9 \\
\hline İş ararken İŞKUR'u kullandım & 112 & 49 & 43,8 \\
\hline İş ararken akraba ve tanıdık kullandım & 112 & 55 & 49,1 \\
\hline İş ararken internet' i kullandım & 112 & 46 & 41,1 \\
\hline İş ararken işyeri ziyaretlerini kullandım & 112 & 30 & 26,8 \\
\hline İş ararken özel istihdam bürolarını kullandım & 112 & 6 & 5,4 \\
\hline
\end{tabular}




\section{Tablo 12}

İşkur'un Hangi Hizmetlerini Biliyorsunuz?

\begin{tabular}{|l|c|c|c|}
\hline & Katılımcı Sayısı & Evet & \% Oran \\
\hline İSKKUR'un mesleki eğitim hizmetini biliyorum. & 112 & 88 & 78,6 \\
\hline İŞKUR'un işe yerleştirme hizmetini biliyorum. & 112 & 75 & 67 \\
\hline İŞKUR'un işsizlik sigortası hizmetini biliyorum. & 112 & 59 & 52,7 \\
\hline İŞKUR'un iş danışmanlı̆̆ı hizmetini biliyorum. & 112 & 26 & 23,2 \\
\hline İŞKUR'un meslek danışmanlı̆̆ hizmetini biliyorum. & 112 & 24 & 21,4 \\
\hline İŞKUR'un işbaşı eğitim programları hizmetini biliyorum. & 112 & 19 & 17 \\
\hline İŞKUR'un girişimcilik hizmetini biliyorum. & 112 & 18 & 16,1 \\
\hline İŞKUR'un TYÇP hizmetini biliyorum. & 112 & 2 & 1,8 \\
\hline
\end{tabular}

\section{Tablo 13}

İş Danışmanlığı Hizmeti İle İlgili Görüşler?

\begin{tabular}{|c|c|c|c|c|c|c|c|c|c|c|c|}
\hline & 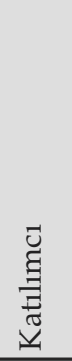 & 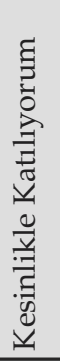 & $\partial^{\circ}$ & 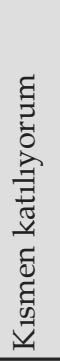 & $0^{\circ}$ & 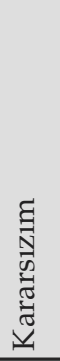 & $0^{\circ}$ & 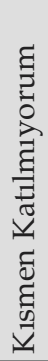 & $\circ^{\circ}$ & 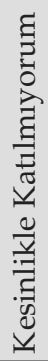 & $\circ^{\circ}$ \\
\hline $\begin{array}{l}\text { İŞKUR bu hizmeti daha fazla } \\
\text { yaygınlaştırmalı }\end{array}$ & 112 & 99 & 88,4 & 6 & 5,4 & 7 & 6,3 & - & - & - & - \\
\hline $\begin{array}{l}\text { İş danışmanlığı hizmetini faydalı } \\
\text { buluyorum }\end{array}$ & 112 & 92 & 82,1 & 12 & 10,7 & 7 & 6,3 & 1 & 0,9 & - & - \\
\hline İş danışmanlığına ihtiyacım var & 112 & 88 & 78,6 & 17 & 15,2 & 7 & 6,3 & - & - & - & - \\
\hline $\begin{array}{l}\text { İş danışmanlığı sonrasında daha bilinçli } \\
\text { olarak iş arayacağım }\end{array}$ & 112 & 87 & 77,7 & 17 & 15,2 & 8 & 7,1 & - & - & - & - \\
\hline $\begin{array}{l}\text { İş danışmanlığı sonrasında İŞKUR } \\
\text { hizmetlerini daha iyi öğrendim. }\end{array}$ & 112 & 84 & 75 & 18 & 16,1 & 9 & 8 & 1 & 0,9 & - & - \\
\hline $\begin{array}{l}\text { İş danışmanlığı hizmetinden memnun } \\
\text { kaldım }\end{array}$ & 112 & 86 & 76,8 & 12 & 10,7 & 13 & 11,6 & 1 & 0,9 & - & - \\
\hline İş danışmanlığı görüşmesi olumlu geçti & 112 & 83 & 74,1 & 15 & 13,4 & 12 & 10,7 & 1 & 0,9 & 1 & 0,9 \\
\hline $\begin{array}{l}\text { İş danışmanlığı bana farklı bakış açısı } \\
\text { kazandırdı }\end{array}$ & 112 & 81 & 72,3 & 19 & 17 & 8 & 7,1 & 2 & 1,8 & 2 & 1,8 \\
\hline İş danışmanlığg İş bulmamı kolaylaştıracak & 112 & 79 & 70,5 & 19 & 17 & 11 & 9,8 & 3 & 2,7 & - & - \\
\hline $\begin{array}{l}\text { İş danışmanlığ } \text { sayesinde iş arama } \\
\text { konusunda motivasyonum arttı }\end{array}$ & 112 & 69 & 61,6 & 32 & 28,6 & 9 & 8 & - & - & 2 & 1,8 \\
\hline
\end{tabular}


İş danışmanlı̆̆ı hizmeti ile ilgili görüşleri genel olarak değerlendirdiğimizde;

danışmanlık hizmeti alan iş arayanların büyük bir çoğunluğu, iş danışmanlığı hizmetini faydalı ve gerekli bulduğu ve İŞKUR'un bu hizmeti arttırması gerektiğini belirttiklerini görmekteyiz. İş arayanlar iş danışmanlığ1 sonrası, İşKUR'un sunmuş olduğu bir çok hizmeti daha iyi öğrendiklerini, iş ararken artık daha bilinçli olarak davranacaklarını ve bu görüşmenin kendilerine farklı bir bakış açısı ve kısmen de olsa iş arama konusunda motivasyon kazandırdığını ifade etmişlerdir. İş arama sürecinde iş danışmanlığına ihtiyaç duyduklarını ve bu hizmetin iş bulmalarını kolaylaştıracağını düşünmekte olup, iş danışmanlığ 1 görüşmesinin olumlu geçtiğini ve bu görüşmeden memnun kaldıklarını belirtmişlerdir.

İş arama süresi ile iş arama sürecinde desteğe olan ihtiyaç ilişkilendirildiğinde, iş arama süreci uzadıkça, iş arayanların iş bulma konusunda desteğe ihtiyaç hissettiklerini görmekteyiz. İş arama süresi ile iş arama sürecinde desteğe olan ihtiyaç arasında doğru orantı olduğunu söyleyebiliriz. Anket sonuçlarına göre süre uzadıkça desteğe olan ihtiyaç artmaktadır.

İş arama sürecinde desteğe olan ihtiyaç ile İ̧KKUR'un iş danışmanlığı hizmetini daha fazla yaygınlaştırılması sorusu ilişkilendirildiğinde, desteğe ihtiyacı olanlar ve olmayanların nerdeyse tamamina yakını bu hizmetin faydalı olduğunu ve arttırılması gerektiğini düşünüyor.

Eğitim Durumu ile iş danışmanlığı hizme-

\section{Tablo 14}

İş Arama Süresi ile, İş Arama Sürecinde Desteğe İhtiyaç Olup Olmadığının İlişkilendirilmesi

\begin{tabular}{|c|c|c|c|c|}
\hline & \multirow[b]{2}{*}{ Süre } & \multicolumn{2}{|c|}{$\begin{array}{c}\text { İş arama sürecinde desteğe } \\
\text { ihtiyacınız olduğunu düşünüyor } \\
\text { musunuz ? }\end{array}$} & \multirow{2}{*}{ Toplam } \\
\hline & & Evet & Hayır & \\
\hline \multirow{6}{*}{$\begin{array}{l}\text { Ne zamandan beri iş } \\
\text { arıyorsunuz? }\end{array}$} & 1 ay- 6 ay & 36 & 8 & 44 \\
\hline & 6 ay - 1 yll & 31 & 3 & 34 \\
\hline & 1 yll - 2 yıl & 20 & 0 & 20 \\
\hline & 2 yll -3 yll & 8 & 0 & 8 \\
\hline & 3 yll - 4 yll & 1 & 0 & 1 \\
\hline & Dört yll üzeri & 5 & 0 & 5 \\
\hline \multicolumn{2}{|c|}{ Toplam } & 101 & 11 & 112 \\
\hline
\end{tabular}

Tablo 15

İş Arama Sürecinde Destek İhtiyacı ve İŞKUR'un Bu Hizmeti Daha Fazla Yaygınlaştırması

\begin{tabular}{|c|c|c|c|c|c|}
\hline & & \multicolumn{3}{|c|}{ İŞKUR bu hizmeti daha fazla yaygınlaştırmalı } & \multirow[b]{2}{*}{ Toplam } \\
\hline & & $\begin{array}{c}\text { Kesinlikle } \\
\text { Katıliyorum }\end{array}$ & $\begin{array}{c}\text { Kismen } \\
\text { Katılıyorum }\end{array}$ & Kararsızım & \\
\hline \multirow{2}{*}{$\begin{array}{l}\text { İş arama sürecinde desteğe } \\
\text { ihtiyacınız olduğunu } \\
\text { düşünüyor musunuz? }\end{array}$} & Evet & 90 & 5 & 6 & 101 \\
\hline & Hayır & 9 & 1 & 1 & 11 \\
\hline \multicolumn{2}{|l|}{ Toplam } & 99 & 6 & 7 & 112 \\
\hline
\end{tabular}




\section{Tablo 16}

Eğitim Durumu ve İş Danışmanlığı Memnuniyeti

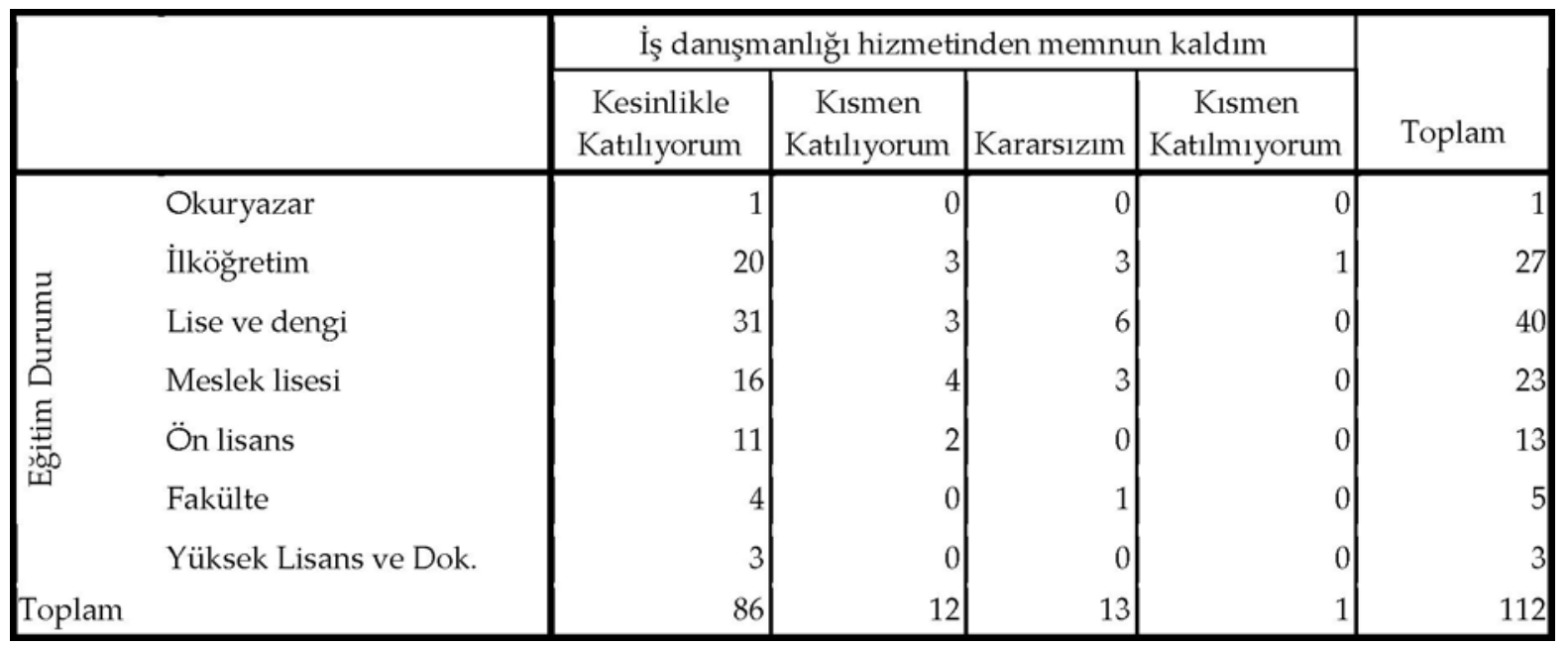

tinden memnun kalma durumu ilişkilendirildiğinde Önlisans, Okuryazar ve Yüksek Lisans düzeyindeki mezunlarının iş danışmanlığı hizmetinden memnuniyet düzeyi yüksek olduğu görülmektedir. İlköğretim mezunu 1 kişi iş danışmanlığı hizmetinden kısmen memnun kalmadığını belirtmiş olmasına rağmen "Kesinlikle" memnun kalmadığını beyan eden olmamıştır. İş danışmanlığı görüşmelerinde genelde ilk görüşme sonrası danışanların, görüşmenin sonucunda hemen işe yönlendirilme ve iş bulunması konusunda beklentileri olduğu için, memnuniyet oranının somut sonuçlar alınabildiği ölçüde artacağı söylenebilir.
İş danışmanlığı hizmetinden memnun kalma ile iş arama süresi ilişkilendirildiğinde, iş arama süresi uzadıkça memnuniyet oranının arttığını görmekteyiz, uzun süreli işsizler iş arama sürecinde desteğe ihtiyaçları olduğunu ve daha önce böyle bir hizmet almış olsalardı, iş arama sürelerinin bu kadar uzamamış olacağını düşündüklerini ifade etmişlerdir. İş arama süresi uzun olmayanlar genelde iş danışmanlığından memnun kalmakla birlikte kısmen kat.lmayanlar ve kararsız olduğunu ifade edenler olmuştur. İşsizlik maaşı alan iş arayanlardan çalışmak istemeyenler iş danışmanlığı hizmetine davet edildiklerinde işsizlik maaşlarının

Tablo 17

İş Arama Süresi ve İş Danışmanlığı Memnuniyeti

\begin{tabular}{|c|c|c|c|c|c|c|}
\hline & & \multicolumn{4}{|c|}{ İş danışmanlığı hizmetinden memnun kaldım } & \multirow[b]{2}{*}{ Toplam } \\
\hline & & $\begin{array}{c}\text { Kesinlikle } \\
\text { Katılıyorum }\end{array}$ & $\begin{array}{c}\text { Kismen } \\
\text { Katıliyorum }\end{array}$ & Kararsızım & $\begin{array}{c}\text { Kısmen } \\
\text { Katılmıyorum }\end{array}$ & \\
\hline \multirow{6}{*}{ 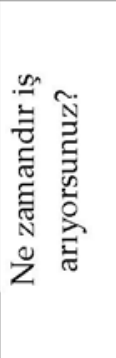 } & 1 ay- 6 ay & 35 & 4 & 5 & 0 & 44 \\
\hline & 6 ay -1 yıl & 23 & 4 & 6 & 1 & 34 \\
\hline & $1 \mathrm{yll}-2 \mathrm{yll}$ & 15 & 3 & 2 & 0 & 20 \\
\hline & 2 yıl - 3 yıl & 7 & 1 & 0 & 0 & 8 \\
\hline & 3 yıl - 4 yıl & 1 & 0 & 0 & 0 & 1 \\
\hline & Dört yıl üzeri & 5 & 0 & 0 & 0 & 5 \\
\hline Toplam & & 86 & 12 & 13 & 1 & 112 \\
\hline
\end{tabular}




\section{Tablo 18}

İş Danışmanlığının Etkisi

\begin{tabular}{|c|c|c|c|c|c|c|}
\hline & \multicolumn{4}{|c|}{$\begin{array}{l}\text { İş danışmanlığı sayesinde iş arama konusunda } \\
\text { motivasyonum arttı }\end{array}$} & \multirow[b]{2}{*}{ Toplam } \\
\hline & & $\begin{array}{l}\text { Kesinlikle } \\
\text { Katılıyorum }\end{array}$ & $\begin{array}{l}\text { Kismen } \\
\text { Katıliyorum }\end{array}$ & Kararsızım & $\begin{array}{c}\text { Kesinlikle } \\
\text { Katılmıyorum }\end{array}$ & \\
\hline \multirow{3}{*}{$\begin{array}{c}\text { İş danışmanlığı } \\
\text { sonrasında daha } \\
\text { bilinçli iş arayacağım }\end{array}$} & Kesinlikle katılıyorum & 65 & 19 & 3 & 0 & 87 \\
\hline & Kısmen Katılıyorum & 4 & 12 & 0 & 1 & 17 \\
\hline & Kararsızım & 0 & 1 & 6 & 1 & 8 \\
\hline Toplam & & 69 & 32 & 9 & 2 & 112 \\
\hline
\end{tabular}

kesilmemesi için İŞKUR'a gelmek zorunda olduklarından memnuniyet düzeyleri düşük olabilmektedir.

İş danışmanlığı sonrasında motivasyon düzeyi ile daha bilinçli iş arayacağım sorusu ilişkilendirildiğinde bireysel iş danışmanlığ görüşmesi sonrası motivasyonu artan iş arayanlar daha bilinçli iş arayacaklarını belirtmiştir. Görüşme sonrası iş arama konusunda motivasyon konusunda karasız olduğunu ifade eden 9 kişiden 3'ü ve motivasyon sorusuna kesinlikle katılmayan 2 kişiden 1' i görüşme sonrası daha bilinçli iş arayacağını belirttiğini görüyoruz. Danışanların işsiz oldukları düşünüldüğünde motivasyon düzeyinin düşük olması normal kabul edilebilir olsa da genel sonuç olarak iş arayanlar danışman desteği sayesinde daha bilinçli iş arayacaklarını ifade etmektedirler.

\section{SONUÇ}

Çalışmamızda iş arayanların çoğu, iş arama sürecinde desteğe ihtiyaç duyduğunu belirterek, bir danışman tarafından dinlenilmenin psikolojik olarak kendilerini rahatlattığını ve kendilerine değer verildiğini hissettiklerini söylemişlerdir.

İşsizliğin önlenmesinde üretimin artırılarak yeni istihdam sahalarının açılması ve istihdam yaratan büyümenin gerekliliği önemli olmakla birlikte, nasıl iş aranacağının bilinmiyor olması ve doğru işi bulma konusunda yaşanan bilgi eksikliği, işsizliğe ve işsizlik süresinin daha uzun olmasına neden olmaktadır. İş danışmanlığı hizmeti sayesinde yaşanan bu sorunların önlenebilmesi ve işgücünün daha etkin olarak kullanılması sağlanabilecektir.

Bu nedenle ülkemizde de tüm iş arayanların, iletişim becerileri kuvvetli, iyi eğitim almış, motivasyonu yüksek uzman personellerden danışmanlık hizmeti alması sağlanmalıdır. İşsizlere iş arama ve özgeçmiş hazırlama yöntemleri muhakkak anlatılmalı, iş arayanlar yalnız bırakılmamalı, iş bulana kadar aktif bir şekilde izlenmeli ve iş arama sürecinde danışmanlık desteği verilmelidir.

İş danışmanlığı hizmetinin daha kaliteli ve verimli bir şekilde işlemesi ve işsizlikle mücadelede etkin olarak kullanılabilmesi için danışmanlık hizmeti verecek olan personel konu hakkında iyi yetişmiş ve nitelikli olmalı ve görevinin gerektirdiği yetki ve sorumlulukla doğru orantılı bir statüye kavuşturulmalıdır.

Sonuç olarak, bu hizmetin iş arayanlarca yeterli düzeyde bilinmediği, danışmanlık hizmeti alan iş arayanlar tarafindan çok olumlu alg1landığ1 ve işsizlik sorununun çözümünde, iş arama, iş bulma ve işi elinde tutma konusunda işsizlere çok önemli katkılar sağlayacağ 1 görülmüştür. Hem literatür taraması esnasında ulaşılan bilgiler hem de çalışmamız esnasında Yalova'dan elde edilen verilerden iş danışmanlığının bu katkıları sağlayacağı anlaşılmıştır. 


\section{Kaynaklar}

Alabaş Aydın, “Uzun Süreli İşsizler Ve Uzun Süreli İşsizliği Azaltmada İŞKUR'un Önemi", İŞKUR Yayınlanmamış Uzmanlık Tezi, Ankara, 2007

Bayhan Mehmet, "Kamu İstihdam Hizmetlerinin Etkinleştirilmesi İçin Daha Geniş Kitlelere Ulaşılmasının Sağlanması ve Yerelleştirme" IŞKUR Uzmanlik tezi, Ankara, 2007

Biçerli, Mustafa Kemal, İşsizlikle Mücadelede Aktif İstihdam Politikaları, T.C. Anadolu Üniversitesi Yayınları, 1.Bask1, Eskişehir, 2004

Biçerli, Mustafa Kemal, Çalışma Ekonomisi, Beta Yayıncılık, 4. Basım, 2007

Blasco, Sylvie, Michael, Rosholm, “The Impact of Active Labour Market Policy on Post-Unemployment Outcomes: Evidence from a Social Experiment in Denmark", Third World Conference EALE - SOLE 2010

Borland, Jeff, and Yi-Ping Tseng, "How do administrative arrangements affect exit from unemployment payments? The case of the Job Seeker Diary in Australia", Melbourne Institute, June 2003

Breunig, Robert, Deborah A. Cobb-Clark, Yvonne Dunlop, Marion Terrill, Assisting the Long-Term Unemployed: Results from a Randomized Trial, Discussion Paper Series, IZA DP No. 628, November 2002

Crepon, Bruno, Muriel Dejemeppe and Marc Gurgand, Counseling the unemployed: does it lower unemployment duration and recurrence?, ANPE (Agence nationale pour l'emploi), October 12, 2004
Ergün Gül, “İşgücü Piyasası Bilgileri, İstihdam ve Danışmanlık Hizmetleri Eğitim Programı", Siyasal Yayıncılık, 2.Bask1, Ankara, Ekim 2000, http:/ / www.direct.gov.uk/en/Employment/Jobseekers/ContactJobcentrePlus/DG_186347, Erişim (29.11.2010)

Euroguidance, Kariyer Yolculuğu, Ankara, 2008.

Forslund, Anders, Alan Krueger, "Did Active Labour Market Policies Help Sweden Rebound from the Depression of the Early 1990s?", Stockholm Un. Publishing, March 12, 2008

Forslund, Anders, Daniela Froberg and Linus Lindqvist, "The Swedish Activity Guarantee", OECD Social, Employment And Migration Working Paper No. 16, Directorate For Employment, Labour And Social Affairs, DELSA/ELSA/WD/SEM(2004)1, 2004

Gorter, Cees, and Guyonne R. J. Kalb. 1996. "Estimating the Effect of Counseling and Monitoring the Unemployed Using a Job Search Model." Journal of Human Resources 31(3):590-610

doi:10.2307/146267

Gerard J. Van Der Berg, Bas Van Der Klaauf, Counseling and Monitoring of Unemployed Workers: Theory and Evidence From A Social Experiment, International Economic Review, Vol. 47, No. 3, August 2006

Gerard J. Van Der Berg, Bas Van Der Klaauf, "Counseling and Monitoring of Unemployed Workers: Theory and Evidence from a Controlled Social Experiment", Discussion Paper Series, IZA DP No. 374, October 2001

Hiç, Mükerrem, Küresel Ekonomik Kriz ve Türkiye, Beykent Üniversitesi Yayınları, İstanbul, 2009 
ILO, World Social Security Report 2010/11, Providing coverage in times of crisis and beyond, International Labour Office-Geneva: ILO, 2010

ILO, Resolution Concerning Human Resources Training and Development, Conclusions concerning human resources training and development, The General Conference of the International Labour Organization, meeting in its 88th Session, 2000

Işığıçok Özlem, Emirgil Burak Faik, "Aktif İşüüü Piyasası Politikaları Ve Mesleki Yetiştirme: İşgücü Yetiştirme Kursları"nın Etkinliğinin Bursa ili Örneğinde İncelenmesi", Sosyal Siyaset Konferansları Dergisi, Sayı 57, 2009

İŞKUR İşlemler El Kitabı, Bölüm 6, II-İş ve Meslek Danışmanlı̆̆1, http:/ / portalint.iskur.local:5253/LoadExternalPage.aspx?uicode=statislemlerelkitabi, Erişim (29.11.2010)

İŞKUR İşlemler El Kitabı, Bölüm 10, İş Arama Becerileri, http:/ / portalint.iskur.local:5253/LoadExternalPage.aspx?uicode=statislemlerelkitabi, Erişim (29.11.2010)

İŞKUR İşlemler El Kitabı, Bölüm 11 İstihdam Terimleri Kavramları, http:/ / statik.iskur.local/tr/kurum_bilgileri/isle mler_elkitabi/bolum $11 /$ bölüm $11 \% 20 \dot{I}$ stihdam\%20Terimleri\%20Kavramları.doc, Erişim (29.11.2010)

İŞKUR Model Ofis Kılavuz Kitapçığı Eki, www.iskurabprojesi.org

İŞKUR 2009 Faaliyet Raporu, Ankara 2010

İŞKUR III. Genel Kurul Raporu, Ankara 2005
TİSK, İşsizlikle Mücadele: Ülke Uygulamaları Ve Türkiye İçin Öneriler, Türkiye İşveren Sendikaları Konfederasyonu Yayın No: 302 Isbn: 978-975-6728-60-4 Aralık 2009, http/ / www.tisk.org.tr/yayinlar.asp?s bj=ana\&ana_id=112 (03/12/2010), Erişim (29.11.2010)

Karabulut Alpaslan, "Türkiye'deki İşsizliği Önlemede Aktif İstihdam Politikalarının Rolü Ve Etkinliği", İŞKUR Yayınlanmamış Uzmanlık Tezi, Ankara, 2007

Karagülle Başak, “Türkiye'de İşsizliğe Bir Çözüm Önerisi Olarak Türkiye İş Kurumu'nun İş Danışmanlığı Hizmetleri", İŞKUR Yayınlanmamış Uzmanlık Tezi, Ankara, 2007

Micklewright, John, Gyula Nagy, Job Search Monitoring and Unemployment Duration in Hungary: Evidence from a Randomised Control Trial, Discussion Paper Series, IZA DP No. 1839, 2005

Nergis Mütevellığlu, Mehmet Zanbak, Ve Mehmet Mert, "İşsizlik, Üniversiteli Gençlik Ve Gelecek: Bir Alan Araştırmasının Bulguları", C.Ü. İktisadi ve İdari Bilimler Dergisi, Cilt 11, Sayı 1, 2010

TÜİK Haber Bülteni, Hane Halkı İşgücü Araştırması 2010 A ğustos Dönemi Sonuçları, (Temmuz, Ağustos, Eylül 2010), http:/ / www.tuik.gov.tr/PreHaberBultenleri.do?id=6355, Erişim (29.11.2010)

T.C. Resmi Gazete, Yurtiçinde İşe Yerleştirme Hizmetleri Hakkında Yönetmelik, Tarihi: 25/04/2009 Sayısı: 27210

T.C. Resmi Gazete, Türkiye İş Kurumu İşgücü Uyum Hizmetleri Yönetmeliği, 31.12.2008 Tarih, 27097/6. Mükerrer Say1l 
Tiryaki Mustafa, Avrupa Birliği Uyum Sürecinde Tarımdan Kopan İşgücünün İstihdam Edilmesinde Aktif İstihdam Politikalarının Rolü Ve Etkinliği, İSKUUR Yayınlanmamış Uzmanlık Tezi, Ankara, 2007

Tokol Aysen, Sosyal Politika, Bursa, 2000

Türkiye İş Kurumu İşgücü Uyum Hizmetleri Yönetmeliği, (Yürürlük Tarihi:31.12.2008 Tarih Ve 27097/6.

Mükerrer Sayılı Resmi Gazete'de Yayımlanmıştır.),

http:/ / Portalint.İskur.Local:5253/Loadexternalpage.Aspx?Uicode=Statyonetmelikler, Erişim (29.11.2010)

Uyar Bozdağlığlu, E.Yasemin, “Türkiye'de İşsizliğin Özellikleri Ve İşsizlikle Mücadele Politikaları", Sosyal Bilimler Dergisi Sayı: 20, 2008

Ünsal, Erdal, Makro İktisat, Turhan Kitapevi, 5.Bask1, Ankara 2003, s.12.

Yavuz Arif, "Küresel Kriz ve İstihdama Etkisi", Sosyal Siyaset Konferansları Dergisi, Say1 58, (2010)

Zaim Sabahattin; Çalışma Ekonomisi, Filiz Kitapevi, 10. Baskı, İstanbul 1997

www.iskur.gov.tr

http:/ / www.job-adviser.com, Erişim (29.11.2010) 
154 "iș, Güç" Endüstri ilișkileri ve İnsan Kaynakları Dergisi

Nisan/April 2011 - Cilt/Vol: 13 - Sayı/Num: 02 